\title{
A Study on E-HRM Practices in different Public and Private Sector Industries
}

\author{
Monalisha Patel \\ Research Scholar \\ Sri Sri University \\ Cuttack 754006 INDIA
}

\author{
Sunil Dhal \\ Associate Professor \\ Sri Sri University \\ Cuttack 754006 INDIA
}

\begin{abstract}
The evolvement of Technology has developed very significantly boosting up the E-HRM to prove its forte. The HRIS and introduction of intranet to the corporate world proved to be a boon. The oomph factor was on the wheels into corporate world when the computer replaced most of the piles of files works. The management in the corporate was firstly accomplished through the use of web portals. The role of technology got a fine touch when introduced to the business management. So the term E-HRM got birth looking at the involvement into the HR activity within the organization. It's obvious that the E-HRM tools reduce the manual labor in management of burden of files. The application of E-HRM practices along its usage is bias free. The firm practices of usage of E-HRM practices stairs the organizational developments into heights without any doubt. So the organizational climate along with its culture and ambience gets to fall in place in a streamlined manner when there is the atmosphere of organizational development as well as sole. The new strategies to be implemented prompts to newer design, creativity and innovation into the running guidelines, principles and policies within the organization where the practices of E-HRM prevail. This proves that the E-HRM boosts to advancement in the form of employee performance allowing them the option to use the self -service method as in the ESS method and the MSS methodology. The out of the box techniques for the employees in their corporate affairs improves them in qualitative wise and the technical assumption keeps hold of them to guide in quality control arena. This particular paper explores the study related to the Internet applications habits in different Public and Private sector industries (companies). As the study finds out that the E-HRM practices followed into various_public and private sector industries(companies) varies to some extent in same or different ways and even discovered that similar to some or the other ways. It was an overall great experience to become an eye witness in profounding such an interesting facts related to E-HRM practices and its usages in different companies within Orissa.
\end{abstract}

\section{Keywords}

Human Resources, Electronic -Human -ResourcesManagement (E-HRM), Human Resources Information Systems (HRIS), Employees satisfaction Level, Public and Private sector companies in Orissa

\section{INTRODUCTION}

HR is a cuisine of varied recipes including Finance, Marketing, IT, Rural Administration, etc. Therefore, it revolves around several of its other specialized areas as well. It's also regarded as the multi-disciplinary ethics. The Human Resources Management (HRM) in it's one of the function of managing the men tactfully also revolves its functionality area in personnel administration and its avid activities. [1] The HR is the qualitative togetherness of premium potential capable admin activities and each manifesting with distinct mission with vision, wants and assignments. The visionary goals so set are predetermined to achieve with strategic planning and performing employees. Therefore there is always a suspension of pressure upon the high end performing employees who delegate the tasks to their sub-ordinates.[2] The execution and implementation of the strategic planning into working modules also affects the pressure level upon the employees on project that in a way describes about the functionalities of the HR. There is an existence of pressure threshold on the HR functionalities with respect to the strategic planning so formulated for the upcoming ventures. The existing activities performing and the activities to be performed add value to the HR functionalities. Those all brings a finesse compliancy to the face of the organization. No doubt that the organizations have sensed the importance of IT and its application tools intervening the HR functionalities, so, this brings the birth to Electronic- Human-Resources - Management into focus. But the revolution of electronic-human -resources-management solely depends upon updating of IT on its first foot starting from the Internet enabled Human Resources Information Systems till web enabled company Intranets_and portals. The running forces are cut -throat race, will to handle taskforces universally, to outstand Human Resources qualitative productivity and attract return on investment. The procedures of electronic-human-resources-management make the tycoons of Human Resources stand as engineers in the making up for corporate amicable techniques. The particular article emphasizes basically on E-HRM practice followed in the different Public and Private sector industries as per the research work happened related to the practices of ElectronicHuman-Resources-Management along with usage of its tools and applications as in the form of software application tools like in NIC (National Informatics Centre), the web portal used for the HRM functionality is called as "e-HRAdm" (electronic human resource administration) system. [3]This would provide the level of satisfaction upon usage of E-HRM and its software application tools in different Public and Private sector companies within Orissa. And this satisfaction impact factor is measured by the Factor Analysis test like the Reliability Statistics Table and the Descriptive Table. The others are Standard Deviation Table, Independent samples Test Table and the Anova Test Table. Thereafter it opens up for various others research wok to be further carried on in near future.

\section{LITERATURE REVIEW}

The intervention of information technology in almost all the facets of business reflects a multi-dimensional, multi-tasking picture of e-commerce. Though the mines, manufacturing and operations sector of industries use heavy machineries instead 
of manual labor but in white collar jobs the job is delegated within the departments by just a click away. Apart from the "clicking "pattern the invention of time saving technology unveiled the "touch screen" approach. It somewhat to some extent proved to be an alien to some as the "touch screen" pattern do not read minds of the operator but touch sensitive. Thus the advancement proves to be an opportunity as well as challenge. The most challenging task is to catch hold of the changing net world in the work zone. With the automation and digitization of the Human-Resources functions to process the work faster is the latest trend.[4] Wright and Dyer (2000) survey state that emerging trends in the work culture of an organization are as rapid as per the changing time that the scope of e-commerce is spreading across. The other names for Information and communication technology with respect to Human Resource Management functions are internet rooted human- resources, human -resource -information system (HRIS), virtual- human- resource -management, humanresource- intranet, system- based -human- resourcemanagement -systems and human- resource- portals still the terminology Electronic -Human-Resources-Management is the trend flourishing. [5]The e-HRM in Indian context is seen avidly by the world. The global change obviously influences the changes across. Certain functional words related to the eHRM practices are automation of work, e-office, transparency, and empowerment. There is an e-revolution over the delivery of the HR services and practices followed in the organization. This present research focuses on the e-HRM tools and application software used in various types of private and public sector organizations. It also focuses on to what extent those organizations practice the e-HRM tools in delivering of the HR services in the state of Odisha. The computerized human resource information system contents the full-fledged Human Resources related -data, information and services, databases, tools and transactions which creates the cocoon of an organizational structure as per Kelley and Reilly (2003).[6] E-HRM has very avidly made its mark by the virtue of enhancement in Technology and its appliances. Organizations introduced technology into their domains in the form of Intranets (corporate intranets) and web-based Human Resource Information Systems. Each and every organization has its own way of gait towards the developmental path. The HR departments at times faced challenges due to the added advantage of utilization of the information technology at very easier and user friendly costs. And this challenge needed to be overcome as the tertiary productivity factor, prices saving along with worth beneficiaries all in all promoted in boosting up the efficiency and effectiveness of the overall productivity. [7]In one of those empirical studies by Sanayei and Mirzaei(2008) aimed at briefing a descriptive explanation about EHRM while debuting its performances with service tools, post the enquiry, the reaction of different independent factor considerations like job satisfaction, professional commitment and organizational commitment on the effectiveness of HRM as the dependent variable. In the reign of the 21 st century, the companies in some or the other ways would have adopted the advanced form of information technology from the advent tools of e-HRM.

HR functional applications (HRFA): The Human Resource Functional Application (HRFA) can be defined as the software based automation of the discrete tasks and added tasks and duties to the personnel administration functionalities (Florkowski and Olivas-Lujan 2006).

Integrated- Human -Resources- software- suite- applications
(ISA): According to the Wikipedia (2014), the integratedsoftware can be defined as the software application tool which can be used for the personal computers which integrates the shared commonality used functionalities of much more productivity software programs into one developed application software . The Integrated Software Suite Application involves itself in deliverance of services like corporate analytics intelligence along with analytics, online analytical data processing, data mining, extracting information, and transformation of data, data warehousing and reporting of data. Those integrated form of data application suite software helps in achieving the highest level of eligibility in efficiency and facilitating overall administration over each personnel administration factors by coordinating every of the company's along with employees information to serve the relevant data instantly as and when required during the operations of the organization starting from the employee's database and its policies to the payroll systems of processing adhered.

Interactive voice response (IVR): The Webpedia (2014) has stated that the Interactive Voice Response can be defined as the form of a communication technology that has been improvised through the usage of advanced form of application technology. The IVR functionalizes when a person uses a touch-tone telephone to exchange with a database to receive information or enter data into the database systems.

HR intranet applications (HRIA): Weidenhammer (2013) in his defined statement stated that the intranet is the virtual hub of all confidential reports and information of an organization. All those confidential human resources information and processes are created as a single and secure repository within an intranet cocoon.

Self-service (SS) applications: Cedar Crestone (2013) in his viewpoint speaks that as per the survey report conducted on the HR functions and management, it's stated that the by implementing the e-HRM tools and applications $10 \%$ number of more employees can serve themselves with the help of advanced form of technology.

Employee self-service (ESS) applications: Florkowski and Olivas-Luján (2006) states that the Employee Self Service (ESS) is that kind of e-HRM application software tool that maintains a group of personnel administration transactions which could be started for interpretation as well finished with proper ease and systematic function irrespective of donating any sort of irritation directly to the personnel department and head of HR.

Manager self-service (MSS) applications: The Manager Self Service software application tool aims at increasing the organizational efficiency by minimizing the extra additional costs and time involved in human resources indulgence between the manager and the employee interactions.

HR extranet applications (HREA): As per Florkowski and Olivas-Luján (2006) the Human Resource Extranet Applications is the private network of the systems that channelizes the data/information of the client companies to the external buyers producing the amalgamation of sources or outsourced personnel administration rendering services. The Human Resource Extranets plays like the medium for ecommerce and transactional business flow.

HR portal applications (HRPA): The Human Resource Portal Application software e-HRM tool is meant to be a networking website medium of interface helpful to the user 
(employees/employer/workforce) that provides a private operating corner to each and every relevant sources of data information, tools and systems.

\section{RESEARCH OBJECTIVE}

This particular paper describes about the study on E-HRM practices in different Public and Private sector industries (companies) within Odisha. From the avid research work and my visit to different Public limited company in Bhubaneswar in Odisha such as National Information Centre (NIC), NALCO, OCAC, OCPL there was to some extent agreeness to some extent of uses of E-HRM tools and software functional application technologies in a similar manner but then the degree of practices related to E-HRM tools varied as per their requirements. NIC used the E-HRM practices as having their own E-HRM software web based portal called as "e-HRAdm(electronic human resource administration) " where it included the functional operating software application system tool as HRFA(Human Resources Functional Application), ISA(Integrated Software Application, HR Portal, HR Extranet, HR Intranet ,Interactive - Voice- Response-(IVR), Employee- self- service(ESS) and Manager- self-service(MSS).Those all software application tools intervenes with the HR(Human Resources) functionalities and provides access to the employees as well as the employers to serve themselves with the Personnel administration Services or the Human Resources Administration services. Likewise NALCO too has its own EHRM web based software application tool/portal to perform the functions of HRM electronically making the manual labor to the least possible use. OCPL on the other hand uses the EHRM practices to the average extent .There could happen to be a limited amount of discussion because the E-HRM practices followed to the utmost level was at the higher end. And on the other hand OCAC obviously used the E-HRM services but then it's a semi-government organization and works on project module basis as and when assigned by the Government and different legal sectors as well. The research found that it's a sister concern to NIC (National Informatics Centre), Bhubaneswar and reports it's all work do to the same. There was almost negligible use of Interactive Voice Response (IVR) in OCAC. In a visit to OCAC, found that there still prevailed the manual intervention in performing the HR activities such as asking for "leaves" and granting for the same. The E-HRM practice was only stringent to the top level in the Management and a bit in the form of decreasing order towards the middle level and almost negligible in the lower level.

But the visit to the Private limited companies like TCS, Edusol, STL and Reliance Jio had a different approach towards the E-HRM practices. As per the discussion with the Procurement Manager Abhisekh Mohanty of Reliance Jio, the E-HRM practices were used for the functions and operations of the organization. Whereas the private limited company Edusols and STL working for Silicon Institute of Technology , Bhubaneswar in its department involved most of the personnel of IT and the head of the department (HR) were one for each respectively. Those companies had the usage of HR -Portal, Employee- self -service(ESS), Manager- selfservice(MSS), HR Extranet, Human Resources Intranet, Interactive Voice Response (IVR), HR Functional application, Integrated Software application tool. Though the HR had to be got reported regarding every activities of the working personnel but then most of those E-HRM services had to be handled by the HR himself. From the corner of TCS (Tata
Consultancy Services) point of view, working personnel from IT named Asutosh conveyed his helping hand in collecting the feedback questionnaire report relating to the usage of Electronic-Human-Resources-Management services practiced in the same. But then the collection was majorly filled up by the personnel (employees) from HR, Finance, and Marketing, IT, Operations and others. And the average statistical report stated that there is even more than average use of the E-HRM software application tools and web based enabled services for the smooth functioning of such top notch competitive IT sector private limited company (industry) within Odisha. The employees preferred the Employee- self -service (ESS) and the Manager- self-service options the most. The HR Extranet, HR Intranet was used at the top level of management the most. The HR portal provided an open platform for all the concerned employers and employees of TCS to exchange, post and share ideas as well as get the relevant information from this E-HRM functionality operational services.

Therefore all in all overall my visit to all those Public and Private sector organizations counting themselves as in total 8 was worth discovering about the usage of E-HRM practices and the updating of techniques related to E-HRM and respectively active participation indulging from the lower level employees to the top level management(employer). The interaction during my research work gained me varied experiences about the understanding of the E-HRM services and practices with the concerned employees of the respective organizations and their way of understanding as well as making, me understand in their feasible language boosted me with larger enthusiasm and excitement to interact with them more and more that made my field work rich with colorful and technical contents.

The Electronic Human Resource Management can be well defined as the developed corporate professional business solution that offers a comprehensive online provision in the management of all procedures and processes, actions, statistics and facts and figures requisite to accomplish Human Resources in a contemporary business organization. The study of E-HRM practices in different (8 as per my research work) Public and Private sector companies in Odisha provided an open ended idea about the inbound activities going on within the organization ( 8 as mentioned in my research work) and their execution process in serving towards the society, country as a whole focusing upon the quality control and going International.

Our objective thus is to figure out the on-going practices related to the E-HRM practices and services in different Public and Private sector organization in Odisha.

\section{RESEARCH DESIGN}

The research has been carried out through a well-defined systematic questionnaire in likert scale for this study. Before the final questionnaire we have done the pilot study through some open ended questionnaire. The data have been collected through different corporates like NIC, OCAC, NALCO, OCPL, RELIANCE JIO, TCS, EDUSOL and STL in Orissa.

The researcher has followed a Stratified Random Technique for the data collection. The strata have been framed by the companies and the respondents have been selected through the random technique. 456 records have been collected for the study.

The data has been analyzed through different statistical tools like Reliability through Cronbach Alpha Test to evaluate the 
questionnaire as well as the validity of the data set, descriptive statistics (Central tendency and Dispersion) to analyze the pattern and the characteristics of the data set, factor analysis to evaluate the end user's perception towards the ERP tools for implementation.

\section{RESEARCH ANALYSIS}

The Factor Analysis can be defined as the most evenly practiced facts and igures/ variable decreasing technique.[8] This multivariate statistical method is used for three vital factors such as minimize the count of variables, from more to less, build related dimensions in between calculated factor components and then built it up and serve a constructive validity proof.

Objective - It is hypothesized that that the application of E-HRM tools are at the same level for Public and Private Organizations.

[9]The purpose of a reliability analysis is to determine how well a set of items, i.e., observed variables, go together into a single scale. This analysis also reveals how strongly each item in the scale is associated with the overall scale. This is called item-total correlations.

The statistic that results from a commonly used reliability analysis is the Cronbach's alpha coefficient. Generally speaking, when a collection of items (i.e., a scale) has a Cronbach's alpha of .70 or larger; the scale is considered to be reliable. This type of reliability analysis refers to the internal consistency of a set of variables.

Table 1:Reliability -Statistics(RS)

\begin{tabular}{|l|l|}
\hline Cronbach's- Alpha & Items in Number \\
\hline .868 & 9 \\
\hline
\end{tabular}

As the reliability value is shown through the following Table 1 drawn below called as the "Reliability Statistics Table" and this particular Table 1 shows the Reliability value of .868 which signifies the validity of the questionnaire and data set are highly significant for the research analysis. The data set is valid and reliable for analysis.

The standard error is quite small. So the standard error .07 means, it's quite negligible.

[10]The parameters tools that are less than .05 are considered to be as Significant whereas more than .05 are considered to be having differences in their opinion regarding the usages of E-HRM services practice in Public and Private limited companies within Odisha.

Table 2: Descriptive

\begin{tabular}{|l|l|l|l|l|}
\hline \multicolumn{2}{|c|}{} & Statistic & Std. Error \\
\hline \multirow{2}{*}{\multicolumn{2}{|l|}{ Mean }} & 3.25 & .125 \\
\cline { 2 - 5 } & $\begin{array}{l}\text { 95\% Confidence } \\
\text { Interval for Mean }\end{array}$ & $\begin{array}{l}\text { Lower } \\
\text { Bound }\end{array}$ & 3.00 & \\
\cline { 2 - 5 } $\begin{array}{l}\text { Apper } \\
\text { Awa of } \\
\text { ERP }\end{array}$ & \begin{tabular}{l} 
Bound \\
\cline { 2 - 5 }
\end{tabular} & 3.49 & \\
\cline { 2 - 5 } & Med -Trimmed-Mean & 3.28 & \\
\cline { 2 - 5 } & Vari & 3.00 & \\
\hline
\end{tabular}

\begin{tabular}{|c|c|c|c|c|}
\hline & Std.- Deviation(SD) & & 1.277 & \\
\hline & Min & & 1 & \\
\hline & Max & & 5 & \\
\hline & Range & & 4 & \\
\hline & Interquartile -Range & & 2 & \\
\hline & Skewness & & -.309 & .236 \\
\hline & Kurtosis & & -.842 & .467 \\
\hline & Mean & & 2.66 & .129 \\
\hline & Confidence & $\begin{array}{l}\text { Lower } \\
\text { Bound }\end{array}$ & 2.40 & \\
\hline & Interval for Mean & $\begin{array}{l}\text { Upper } \\
\text { Bound }\end{array}$ & 2.91 & \\
\hline & 5\%- Trimmed- Mean & & 2.62 & \\
\hline & Med & & 3.00 & \\
\hline capa & Vari & & 1.747 & \\
\hline to & Std.- Deviation(SD) & & 1.322 & \\
\hline ERP & Min & & 1 & \\
\hline & Max & & 5 & \\
\hline & Range & & 4 & \\
\hline & Interquartile- Range(II & & 3 & \\
\hline & Skewness & & .225 & .236 \\
\hline & Kurtosis & & -1.068 & .467 \\
\hline
\end{tabular}

The Descriptive Factor Analysis defines itself as the altogether compatibility of variable_components that couldn't be stated as being drawn from a good-explained mass, the assumption in figures of communalities, mass parameters, and global components isn't a rational undertaking. A descriptive factor analysis can be outstand by volumning test vectors inversely as the components of total test variance unable to predict a test battery common factor. Those factor variables are in a good way explained and a descriptive factor analysis rooted on weighting by such components requires no assumptions about the masses as well as no future predictions of masses; it demands only that regressions be fairly linear. In this Table 2 known as the "Descriptive Statistics " , it indicates the mean of Awareness regarding ERP which is 3.25 that indicates the most of the end users are aware about the ERP (Enterprise Resource Planning) software tool by different environment like the top management, news, journals and some other sources . Even it's found that they are very much confident about their awareness because it lies between $3-3.49$. The standard error is quite negligible that is .125 which signifies the opinion of the end users. The Skewness and Kurtosis value signifies the Normality of the 
data set.

Next, in the segment of "Capable to handle ERP", it indicates the mean of capable of handling ERP which is 2.66 that indicates the most of the end users are capable of handling the ERP (Enterprise Resource Planning) software tool by different environment like the top management, news, journals and some other sources. Even it's found that they are very much confident about handling the ERP because it lies between $2.40-2.91$.The standard error is quite negligible that is .129 which signifies the opinion of the end users. The Skewness and Kurtosis value signifies the Normality of the data set.

Table 3: Group Statistics

\begin{tabular}{|c|c|c|c|c|c|}
\hline & $\begin{array}{l}\text { Types of } \\
\text { company }\end{array}$ & $\mathrm{N}$ & Mean & $\begin{array}{l}\text { Std. } \\
\text { Deviat } \\
\text { ion }\end{array}$ & $\begin{array}{l}\text { Std. } \\
\text { error } \\
\text { mean }\end{array}$ \\
\hline \multirow[t]{2}{*}{ IVR } & Public & 252 & 1.85 & 1.151 & .072 \\
\hline & Private & 194 & 2.69 & 1.299 & .093 \\
\hline \multirow{2}{*}{$\begin{array}{l}\mathrm{Hr} \\
\text { intranet }\end{array}$} & Public & 250 & 3.20 & 1.305 & .083 \\
\hline & Private & 198 & 3.39 & 1.173 & .083 \\
\hline \multirow[b]{2}{*}{$\begin{array}{l}\text { Employ } \\
\text { ee self } \\
\text { service- } \\
\text { manger } \\
\text { self } \\
\text { service }\end{array}$} & Public & 254 & 3.09 & 1.245 & .078 \\
\hline & Private & 198 & 3.43 & 1.096 & .078 \\
\hline \multirow{2}{*}{$\begin{array}{l}\mathrm{Hr} \\
\text { extranet }\end{array}$} & Public & 252 & 2.77 & 1.337 & .084 \\
\hline & Private & 200 & 3.20 & 1.160 & .082 \\
\hline \multirow{2}{*}{$\begin{array}{l}\mathrm{Hr} \\
\text { protal }\end{array}$} & Public & 252 & 3.24 & 1.214 & .076 \\
\hline & Private & 200 & 3.46 & 1.129 & .080 \\
\hline \multirow{2}{*}{$\begin{array}{l}\mathrm{Hr} \\
\text { function } \\
\text { al } \\
\text { applicat } \\
\text { ion }\end{array}$} & Public & 252 & 3.09 & 1.318 & .083 \\
\hline & Private & 200 & 3.11 & 1.235 & .087 \\
\hline \multirow{2}{*}{$\begin{array}{l}\text { Integrat } \\
\text { ed } \\
\text { suited } \\
\text { applicat } \\
\text { ion }\end{array}$} & Public & 252 & 2.654 & 1.264 & .808 \\
\hline & Private & 198 & 2.85 & 1.187 & .084 \\
\hline
\end{tabular}

- Here the Mean so calculated is $\mathbf{. 2 5 2}$ and the Mean Standard error for the different tools of E-HRM for the Public and Private sector industries have been evaluated through this Table 3 (Group Statistics). The tool parameters for the E-HRM are Interactive Voice Response (IVR), Human Resources Functional Application (HRFA), HR Portal, HR Extranet, Human-Resources- Intranet, Employee Self-service (ESS), Manager- Self-service (MSS) and the Integrated Application Software Suite Application Tool (ISA).Almost we have taken 252 respondents from the Public sector Company and 194 from the Private sector Company.

- The Mean of Interactive Voice Response (IVR) and Integrated Suite Application software tool are less than 3 and other cases are greater than 3. From this it can be concluded that the end users within the Public and Private limited companies are in the favor of "strongly agree" regarding the usages of tools related to the E-HRM practices within their respective organizations that indicate those are greater than 3 .
- The standard error in all those cases is negligible which approximately $\mathbf{. 0 7}$ is the finding.

Table 4: Independent sample Test

\begin{tabular}{|c|c|c|c|c|}
\hline & & \multicolumn{3}{|c|}{ t-test for Equality of Means } \\
\hline & & $\mathrm{df}$ & $\begin{array}{l}\text { Sig. } \\
(2- \\
\text { taile } \\
\text { d) }\end{array}$ & $\begin{array}{l}\text { Mean } \\
\text { Differe } \\
\text { nce }\end{array}$ \\
\hline \multirow[b]{2}{*}{ IVR } & $\begin{array}{l}\text { Equal } \\
\text { variances } \\
\text { assumed }\end{array}$ & 444 & .000 & -.842 \\
\hline & $\begin{array}{l}\text { Equal } \\
\text { variances } \\
\text { not } \\
\text { assumed }\end{array}$ & $\begin{array}{l}387.8 \\
50\end{array}$ & .000 & -.842 \\
\hline \multirow{2}{*}{$\begin{array}{l}\text { HR } \\
\text { INTRA } \\
\text { NET }\end{array}$} & $\begin{array}{l}\text { Equal } \\
\text { variances } \\
\text { assumed }\end{array}$ & 446 & .103 & -.194 \\
\hline & $\begin{array}{l}\text { Equal } \\
\text { variances } \\
\text { not } \\
\text { assumed }\end{array}$ & $\begin{array}{l}438.8 \\
24\end{array}$ & .099 & -.194 \\
\hline \multirow{2}{*}{$\begin{array}{l}\text { EMPL } \\
\text { OYEE } \\
\text { SELF } \\
\text { SERVI } \\
\text { CE- } \\
\text { MANA } \\
\text { GERS } \\
\text { SELF } \\
\text { SERVI } \\
\text { CE }\end{array}$} & $\begin{array}{l}\text { Equal } \\
\text { variances } \\
\text { assumed }\end{array}$ & 450 & .002 & -.348 \\
\hline & $\begin{array}{l}\text { Equal } \\
\text { variances } \\
\text { not } \\
\text { assumed }\end{array}$ & $\begin{array}{l}443.3 \\
41\end{array}$ & .002 & -.348 \\
\hline \multirow{2}{*}{$\begin{array}{l}\text { HR } \\
\text { EXTR } \\
\text { ANET }\end{array}$} & $\begin{array}{l}\text { Equal } \\
\text { variances } \\
\text { assumed }\end{array}$ & 450 & .000 & -.430 \\
\hline & $\begin{array}{l}\text { Equal } \\
\text { variances } \\
\text { not } \\
\text { assumed }\end{array}$ & $\begin{array}{l}446.3 \\
71\end{array}$ & .000 & -.430 \\
\hline \multirow{2}{*}{$\begin{array}{l}\text { HR } \\
\text { PORT } \\
\text { AL }\end{array}$} & $\begin{array}{l}\text { Equal } \\
\text { variances } \\
\text { assumed }\end{array}$ & 450 & .047 & -.222 \\
\hline & $\begin{array}{l}\text { Equal } \\
\text { variances } \\
\text { not } \\
\text { assumed }\end{array}$ & $\begin{array}{l}438.7 \\
81\end{array}$ & .045 & -.222 \\
\hline \multirow{2}{*}{$\begin{array}{l}\text { HR } \\
\text { FUNC } \\
\text { TIONA } \\
\text { L } \\
\text { APPLI } \\
\text { CATIO } \\
\mathrm{N}\end{array}$} & $\begin{array}{l}\text { Equal } \\
\text { variances } \\
\text { assumed } \\
\end{array}$ & 450 & .852 & -.023 \\
\hline & $\begin{array}{l}\text { Equal } \\
\text { variances } \\
\text { not } \\
\text { assumed }\end{array}$ & $\begin{array}{l}437.7 \\
66\end{array}$ & .851 & -.023 \\
\hline \multirow{2}{*}{$\begin{array}{l}\text { INTEGR } \\
\text { ATED } \\
\text { SUIT } \\
\text { APPLIC } \\
\text { ATION }\end{array}$} & $\begin{array}{l}\text { Equal } \\
\text { variances } \\
\text { assumed }\end{array}$ & 448 & .091 & -.198 \\
\hline & $\begin{array}{l}\text { Equal } \\
\text { variances } \\
\text { not } \\
\text { assumed }\end{array}$ & $\begin{array}{l}434.0 \\
92\end{array}$ & .089 & -.198 \\
\hline
\end{tabular}




\section{Independent Sample Test}

- This table indicates the Interactive Voice Response (IVR), Human Resources Functional Application (HRFA), HR Portal, HR Extranet, HumanResources- Intranet, Employee -Self-service (ESS), Manager- Self-service (MSS) and the Integrated Application Software Suite Application Tool (ISA) as its parameters of tools.

- From this Independent Sample Test Table, it can be conclude that the E-HRM software application tools that we have taken as the statistical parameters for calculation define as the ones that are greater than .05 have differences in opinion regarding the practices of E-HRM tools and services within the Public and Private limited companies (industries) within Odisha.

- And the ones that are same in decimal degree have same opinion regarding the practices of E-HRM tools and services within the Public and Private limited companies (industries) within Odisha.

Table 5: ANOVA Test

\begin{tabular}{|c|c|c|}
\hline & & Sig. \\
\hline \multirow{3}{*}{ IVR } & $\begin{array}{l}\text { Between } \\
\text { Groups }\end{array}$ & .000 \\
\hline & $\begin{array}{l}\text { Within } \\
\text { Groups }\end{array}$ & \\
\hline & Total & \\
\hline \multirow{3}{*}{$\begin{array}{l}\text { HR } \\
\text { INTRANET }\end{array}$} & $\begin{array}{l}\text { Between } \\
\text { Groups }\end{array}$ & .103 \\
\hline & $\begin{array}{l}\text { Within } \\
\text { Groups }\end{array}$ & \\
\hline & Total & \\
\hline \multirow{3}{*}{$\begin{array}{l}\text { EMPLOYEE } \\
\text { SELF } \\
\text { SERVICE- } \\
\text { MANAGERS } \\
\text { SELF } \\
\text { SERVICE }\end{array}$} & $\begin{array}{l}\text { Between } \\
\text { Groups }\end{array}$ & .002 \\
\hline & $\begin{array}{l}\text { Within } \\
\text { Groups }\end{array}$ & \\
\hline & Total & \\
\hline \multirow{3}{*}{$\begin{array}{l}\text { HR } \\
\text { EXTRANET }\end{array}$} & $\begin{array}{l}\text { Between } \\
\text { Groups }\end{array}$ & .000 \\
\hline & $\begin{array}{l}\text { Within } \\
\text { Groups }\end{array}$ & \\
\hline & Total & \\
\hline \multirow{3}{*}{ HR PORTAL } & $\begin{array}{l}\text { Between } \\
\text { Groups }\end{array}$ & .047 \\
\hline & $\begin{array}{l}\text { Within } \\
\text { Groups }\end{array}$ & \\
\hline & Total & \\
\hline \multirow{3}{*}{$\begin{array}{l}\text { HR } \\
\text { FUNCTIONAL } \\
\text { APPLICATION }\end{array}$} & $\begin{array}{l}\text { Between } \\
\text { Groups }\end{array}$ & .852 \\
\hline & $\begin{array}{l}\text { Within } \\
\text { Groups }\end{array}$ & \\
\hline & Total & \\
\hline \multirow{3}{*}{$\begin{array}{l}\text { INTEGRATED } \\
\text { SUIT } \\
\text { APPLICATION }\end{array}$} & $\begin{array}{l}\text { Between } \\
\text { Groups }\end{array}$ & .091 \\
\hline & $\begin{array}{l}\text { Within } \\
\text { Groups }\end{array}$ & \\
\hline & Total & \\
\hline
\end{tabular}

ANOVA Test

From this above mentioned Anova Test table the conclusion regarding the E-HRM services and its practices within the
Public and Private limited company within Odisha that the tools parameters taken into account for calculation show a decimal degree of usages. Therefore, the parameters below .05 ratings are having same opinion regarding the E-HRM services practice in Public and Private limited companies within Odisha and the parameters counting above .05 is having differences in their opinion regarding the usages of E-HRM tools and services practice in Public and Private limited companies within Odisha.

\section{CONCLUSION}

From the above findings and tabular diagrams of statistical approach it can be conclude that the E-HRM practices related to its tools and services within the Public and Private limited companies within Odisha revolved around .05 statistical measure taking into consideration the Factor Analysis in Research analysis involving the Reliability Test, Descriptive Test, Table 3, Independent Sample Test and the ANOVA test. Those all findings concluded that there were averagely same as well varying in opinions regarding the E-HRM services practices. Future scope for the study could be on effectiveness of E-HRM practices in different public and private sector industries

\section{REFERENCES}

[1] Monalisha Patel, Sunil Dhal, May 17 Volume 5 Issue 5, "The Virtual Ambience with Electronic Human Resource Management System: A Systematic Literature Review", International Journal on Recent and Innovation Trends in Computing and Communication (IJRITCC), ISSN: 23218169, PP: $1059-1063$

[2] Rajendra Behera, Sunil Dhal, May 17 Volume 5 Issue 5, "Activity Process Re-Engineering-Greatest Challenges In Implementation of ERP Systems in Government Organization", International Journal on Recent and Innovation Trends in Computing and Communication (IJRITCC), ISSN: 2321-8169, PP: 540 - 544

[3] Human Resource Information Systems: Basics, Applications and future directions (2nd Ed.).

[4] Thousand Oaks, CA: Sage Publications.

[5] www.shrm.org

[6] Bondarouk, T. \&Looise, J.K., (2009).A Contingency Perspective on the Implementation of E-Performance Management, 197-202.In: Encyclopaedia of Human Resources Information Systems: Challenges in E-HRM. Ed.Teresa Torres-Coronas \& Mario Arias-Oliva. IGI global Books, Pennsylvania USA.

[7] Bondarouk, T. \&Rule, H. (2005),"Does E-HRM contribute to HRM effectiveness? Results from a quantitative study in a Dutch ministry", paper presented at the 4th International Conference of the Dutch HRM Network, November 4-5.2006, Enscheda, The Netherlands.[online] [cited 2010 -09-20],

[8] Brown, D. (1999). Technology a tool for strategic HR. Canadian HR reporter 18-19.

[9] Busser, L., \& Davis, E. (2002).Information systems: the quiet revolution in human resource management. Journal of Computer Information Systems 42:2, 17-20.

[10] http://documents.routledgeinteractive.s3.amazonaws.com /9781138838345/student/chap_sum/chapter_summary_c h15.pdf 
[11] Monalisha Patel,Sunil Dhal, VOLUME NO. 7 (2017), ISSUE NO. 08 (AUGUST) ISSN 2231-5756 "A STUDY ON ELECTRONIC-HUMAN RESOURCE MANAGEMENT AND ITS STRATEGIES: LITERATURE REVIEW "INTERNATIONAL JOURNAL OF RESEARCH IN COMMERCE, IT \& MANAGEMENT A Monthly Double-Blind Peer Reviewed (Refereed/Juried) Open Access International e-Journal - Included in the International Serial Directories http://ijrcm.org.in/.
[12] Monalisha Patel,Sunil Dhal, ISSN 0976-495X (Print) www.anvpublication.org 2321-5763 (Online) RESEARCH ARTICLE "An Exploratory Study on Electronic Human Resource Management (E-HRM) Tools Implemented In Different Industry in Odisha "Research Scholar, Sri Sri University, Cuttack, Odisha. *Corresponding Author E-mail: monalisha.patel10@gmail.com, sunildhal@ srisriuniversity.edu.in 